\title{
Histology for the Visually Impaired: A Study Applying Models at Universities in Spain and Brazil
}

\author{
Histología para Discapacitados Visuales: Un Estudio Aplicando \\ Modelos en Universidades de España y Brasil
}

\author{
Michele Waltz Comarú ${ }^{1,2}$; Renato Matos Lopes ${ }^{2,3}$; Cecília Galvão² \& Cláudia Mara Lara Melo Coutinho ${ }^{4,5}$
}

COMARÚ, M. W. ; LOPES, R. M.; GALVÃO, C. \& COUTINHO, C. M. L. M. Histology for the visually impaired: a study applying models at universities in Spain and Brazil. Int. J. Morphol., 39(1):235-243, 2021.

SUMMARY: This study aimed to develop models that reproduce histological slide images and evaluate them with blind and sighted students from an inclusion perspective. A questionnaire with questions about the ideal characteristics of a model was answered by visually impaired (VI) students. Based on the responses and optical microscopy images from histological atlases, nine models were constructed with standardized materials. The models were tested at different times with VI students and with students who see. Our results indicate that morphology teaching, according to the students themselves, should make use of extra resources, such as models. The ideal characteristics for model efficiency as a teaching tool were representative textures and reliefs. The models built were evaluated by blind students in Spain and sighted students in Brazil because, from an inclusive perspective, it is ideal that the same material can meet the demands of all types of students. The use of the developed models enhanced learning in both groups, even when combined with microscopes for sighted students. According to student opinions, the use of relief models can represent an important pedagogical strategy used to teach morphological. The importance of developing that materials was also highlighted from an inclusion perspective, as these materials can be used in mixed classes, all students together, in cooperative learning. This study aids morphological subject teachers who teach visually impaired students to know where to start on the path to an inclusive and pedagogically coherent learning process.

KEY WORDS: Visually impaired undergraduates; Models; Morphology teaching.

\section{INTRODUCTION}

In general, courses in the biomedical field usually present morphological disciplines in their curriculum structure, such as cell biology, histology and embryology (Felszeghy et al., 2019). These disciplines have traditionally used optical and electron microscopy images as educational resources to understand organ, tissue and cell structure and function (Caballero González, 2012; Lee et al., 2018). Such resources - essentially profoundly visual - cannot be achieved by visually impaired (VI) students and, thus, become insufficient in an education system that proposes to be inclusive (McLeskey \& Waldron, 2011). In this sense, any alternative related to morphological discipline class teaching methodologies that promote equal opportunity regarding appropriation and access to contents taught to all students (including VI) would be welcome (Abed \& Shackelford,
2020). Specific resources, methods and materials for teaching morphology to students with disabilities are still experimental and scarce in the scientific literature (Glat \& Pletsch, 2010; Comarú et al., 2014).

To the extent that morphological discipline contents are essential in the training of biomedical professionals (Sansgiry, 2004; Witt-Enderby \& McFalls-Stringert, 2004; Campos-Sánchez et al., 2014) and that, concomitantly, the educational procedures and resources of the so-called "traditional" teaching method do not offer all the conditions that guarantee VI student learning, this study was developed with two main objectives: 1) Collaboratively develop relief and texture models that reproduce histological slide images with students and teachers from the Physiotherapy School

\footnotetext{
${ }^{1}$ Instituto Federal do Rio de Janeiro, campus Mesquita 26582-000, Mesquita, RJ, Brazil.

${ }^{2}$ Instituto de Educação da Universidade de Lisboa, Alameda da Universidade, 1649-013, Lisboa - Portugal.

${ }^{3}$ Laboratório de Comunicação Celular (LCC), Instituto Oswaldo Cruz - IOC/FIOCRUZ, 21040-360, Rio de Janeiro, RJ, Brazil.

${ }^{4}$ Laboratório de Inovações em Terapias, Ensino e Bioprodutos (LITEB), Instituto Oswaldo Cruz - IOC/FIOCRUZ, Rio de Janeiro - RJ, Brazil.

${ }^{5}$ Instituto de Biologia - Campus do Valonguinho, 24210-130, Niterói, RJ, Brazil.
} 
of the National Organization of the Spanish Blind / Escuela Universitaria de Fisioterapia de la organización nacional de ciegos españoles (EUF-ONCE) and; 2) Evaluate strategies using the developed materials that enable access to morphological contents with both VI and sighted students.

This article was produced in Brazil in cooperation with a Spanish University and arose from the interest in developing materials and presenting how to teach VI students and the resources actually used in an already structured educational context such as that of the EUF-ONCE in Madrid.

Thus, the main objective of this work was to develop the tactile models of histological slide images having as a parameter the characteristics pointed out by the VI students, and to evaluate them in practical morphology classes, with the hypothesis that the use of the models, even under conditions and with different uses by sighted and blind students, it promotes more inclusive and efficiently productive morphology classes for both types of students.

\section{MATERIAL AND METHOD}

Research with EUF VI students on characteristics valued in the applied teaching methods concerning morphological subjects: A questionnaire consisting of openended questions was answered by fourteen EUF VI students, male and female, blind or presenting low-vision, aged 1926 , representing all the students in the first year class of this physiotherapy school. During the research period, these students were studying the two morphological content subjects of the course ("Anatomy" and "Physiology and Biochemistry"). The questionnaire consisted of five open questions. A specific variable was investigated for each question, as displayed in Table I.
Based on the written answers, an election of key terms was made taking into account the citation frequency in the answers.

Development of histological models: Optical microscopy images were selected from two histology atlases (Gartner \& Hiatt, 2003; Junqueira \& Carneiro, 2004) and were used as reference for the handmade models. Several materials were tested for differentiated tactile representations of shapes, textures and reliefs. Similar structures in different models have been standardized to always be represented by the same material.

Model evaluation: Twoassessment sessions were held: (i) with EUF VI students located in Madrid, Spain and; (II) with sighted students from the Vila Velha University (UVV) located in Brazil. An evaluation by blind people, according to Jones et al. (2009) is vital in order to understand the real understanding of these students. Due to the fact that there is a university of biomedical sciences specifically for the blind in Spain, the studies were conducted with two different populations in two different countries.

At the EUF, the histological models were tested with eight first year VI students. All students had access to the theoretical class content through twice-repeated audio version of the text book, each lasting 10 minutes each from a textbook available from the EUF library on CD (Poirier et al., 2002). The text contained the following information and was distributed in chapters, as follows:

- Chapter 1: Tissue concept; tissue definition - The four families/types of tissues.

- Chapter 2: Coating epithelia - lining epithelia polarization - Absence of epithelia blood capillaries - Epithelia innervation.

Table I. Questions elaborated from variables comprising the questionnaire applied to visually impaired students at the University School of Physiotherapy of the National Organization of the Spanish Blind - ONCE.

\begin{tabular}{|c|c|}
\hline VARIABLES & DEVELOPED QUESTIONS \\
\hline $\begin{array}{l}\text { VARIABLE 1: Methods used in this school for } \\
\text { teaching morphological subjects. }\end{array}$ & $\begin{array}{l}\text { 1) What types of adaptations are used in the practical and } \\
\text { theoretical classes of the subjects that present Cell Biology and } \\
\text { Histology contents? }\end{array}$ \\
\hline VARIABLE 2: Method efficiency. & $\begin{array}{l}\text { 2) Do you consider that the applied adaptations are sufficiently } \\
\text { efficient for your learning? }\end{array}$ \\
\hline $\begin{array}{l}\text { VARIABLE 3: Concrete needs for image } \\
\text { understanding by VI students. }\end{array}$ & $\begin{array}{l}\text { 3) Do you miss something concrete like models, for example, for } \\
\text { a better definition of biological images? }\end{array}$ \\
\hline $\begin{array}{l}\text { VARIABLE 4: Contribution of the use of } \\
\text { relief models for learning. }\end{array}$ & $\begin{array}{l}\text { 4) In your opinion, does the use of microscopic relief models in } \\
\text { the classroom seem to be something that can contribute to the } \\
\text { learning of morphological disciplines? }\end{array}$ \\
\hline $\begin{array}{l}\text { VARIABLE 5: Important features of relief } \\
\text { models. }\end{array}$ & $\begin{array}{l}\text { 5) What characteristics should such models present? And which } \\
\text { should they not? }\end{array}$ \\
\hline
\end{tabular}


The students were then divided into two groups: GROUP 1, which had no contact with the models, and GROUP 2, which had 10 minutes to manipulate the models.

A written evaluation - an objective test containing five answer options - with questions concerning the studied content, was then provided to both groups. The data obtained from the evaluations were subjected to statistical analyses using an: ANOVA comparison test followed by Tukey's multiple comparison test.

At the UVV, 21 research students enrolled in the Biological Sciences course, both male and female, aged between 18 and 27 years old, participated in the study, representing all students of the second morning class enrolled in the "Histology and Embryology" discipline.

The models were tested in four meetings, applying the following conditions: After being presented the theoretical contents in an oral expository form (by the teacher), the students were separated into three groups: GROUP 1, which took practical classes using only microscopes (traditional classes); GROUP 2, which conducted practical classes using only the models, and GROUP 3, which made use of both microscopy and model manipulation.

The division of the three groups was not random. A previous analysis of student performance was performed in previous evaluations, so that the groups were intentionally heterogeneous, comprising low, medium and high performance students proportionally distributed among the three groups.

Each class began with an assessment consisting of the observation of a printed image of the histological section studied in the previous class and the indication of 10 studied structures with a pen. The assessment was identical for all groups. This process was repeated three times, covering 4 weeks, as displayed in Figure 1B.

The data obtained from sighted students were also analyzed through an ANOVA test followed by Tukey's multiple comparison test. Figure 1 displays a comparative scheme of inter-group procedure differences.

It is important to highlight that, during this study, all students obtained conceptually the same content of the models as their colleagues with vision. In accordance with the principles of the Declaration of the World Medical Association of Helsinki on Ethical Principles for Medical Research involving Human Beings, this research was approved by the research ethics committee of Fiocruz / RJ with the registration number 484/08. All research participants gave their consent by signing a free and informed consent form (presented in Portuguese, Spanish and Braille).

\section{VI students from the EUF in Spain}
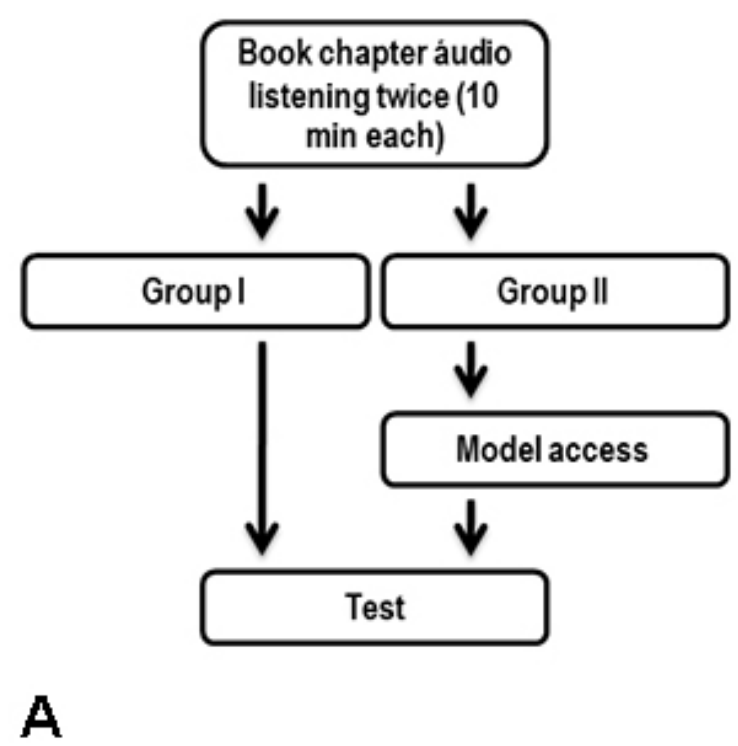

B

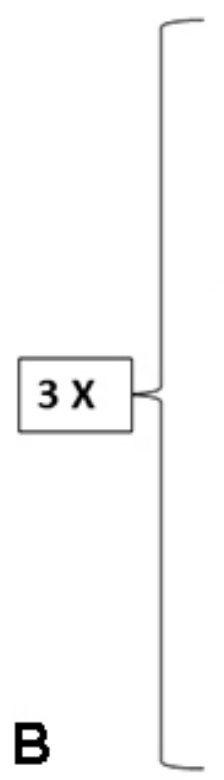

\section{Sighted students from Vila Velha University (UVV) in Brazil}

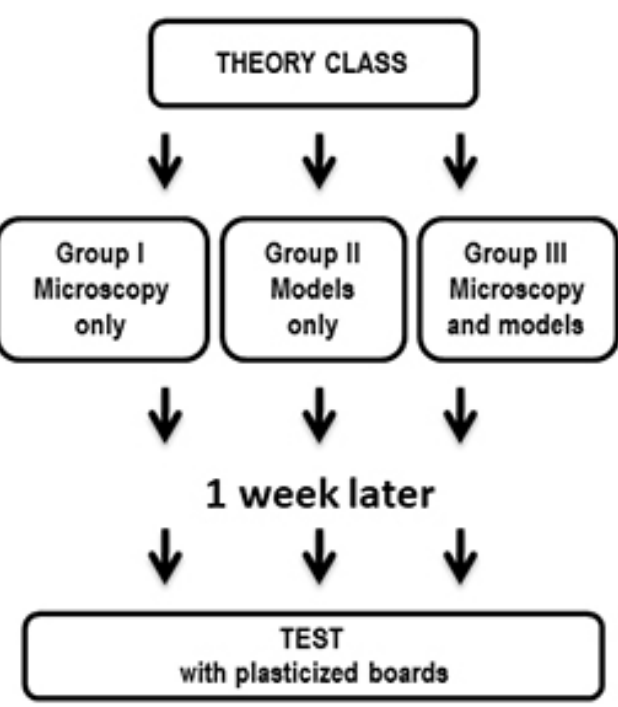

Fig. 1. Scheme of how class and evaluations were conducted with visually impaired (VI) students from the Escuela Universitaria de Fisioterapia (EUF) in Spain (A) and with sighted students from VilaVelha University (UVV) in Brazil (B). 


\section{RESULTS AND DISCUSSION}

What do VI students have to say? - As stated in the introduction, the aim of this study was to build models, but in a collaborative and non-arbitrary way, in order to address the needs pointed out by VI students, declared by themselves in response to a questionnaire specially designed for this investigation. Therefore, the first question presented to EUF VI students was "What types of adaptations are used in the practical and theoretical classes of subjects that present Cell Biology and Histology contents?". Relief models and mockups were the most cited by blind students, as indicated in Figure 2A.

A similar study conducted at the University of Valencia (Avila, 1998) pointed out that transcriptions in Braille and audio class recordings represented the most widely used resources (55\% and $35 \%$, respectively) to understand theoretical content. However, our data indicate that teaching practical morphology content to the visually impaired should also present extra resources (such as models, for example).

The use of models in classes is recognized as a valid pedagogical strategy for sighted biology teaching (AraújoJorge et al., 2004; Husmann et al., 2009; Tian et al., 2014). However, such a resource receives special value from the point of view of teaching the blind, not only as a pedagogical

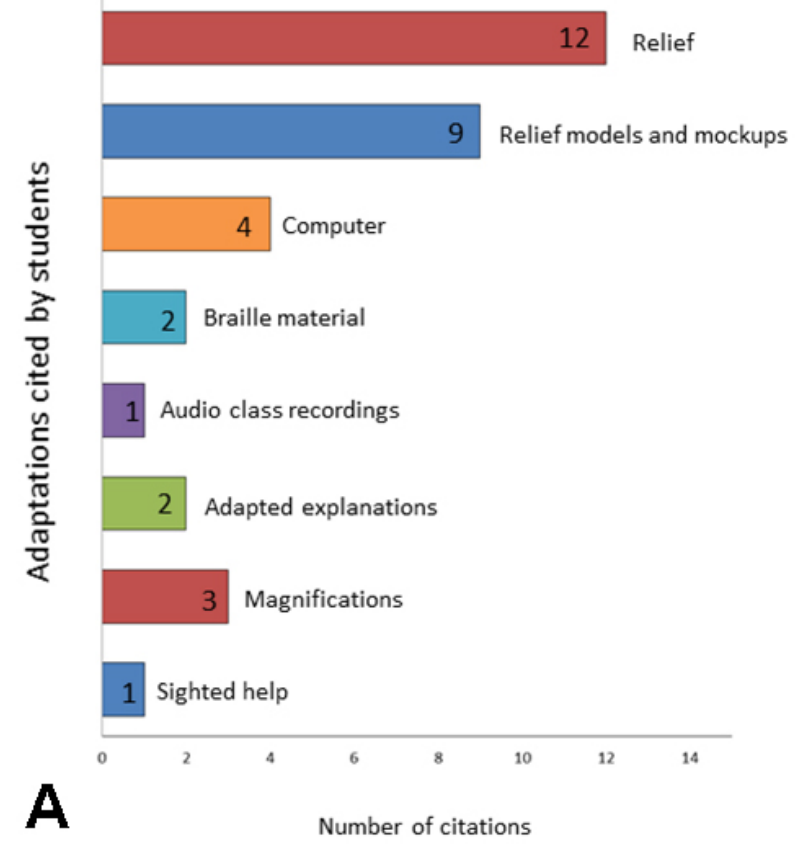

alternative, but as a key part of the teaching-learning process (Smothers \& Goldston, 2010; Boyd-Kimball, 2012; Tiznado-Matzner et al., 2019).

When asked about the efficiency of the methods used in classes on subjects presenting morphological content (question 2 - Table II), 13 of the 14 interviewed students stated that they felt sufficiently satisfied, which indicates that the path to the methodological adaptation of morphology classes, according to the students, goes through model construction. However, 8 responses indicated terms related to low sensitivity or low definition, indicating that improvement concerning the used materials is required.

It was noted that it is important for theVI to have something concrete and tangible, so that they can create the spatial notion of a morphological structure described in a text or in a speech by a class teacher (Barbosa-Lima, 2012). A total of nine of the 14 students affirmed this need when answering the question related to the need for concrete models (question 3 - Table II). The other 5 stated that the model is not a necessity but works as a complement that optimizes the class. Our results corroborate the idea presented by other studies (García et al., 2019; Gould et al., 2019) that state that graphic representations that are essentially assimilated by sight can also be perceived by touch and that a VI person depends on touch to form spatial concepts and create internal images (Melaku et al., 2016).

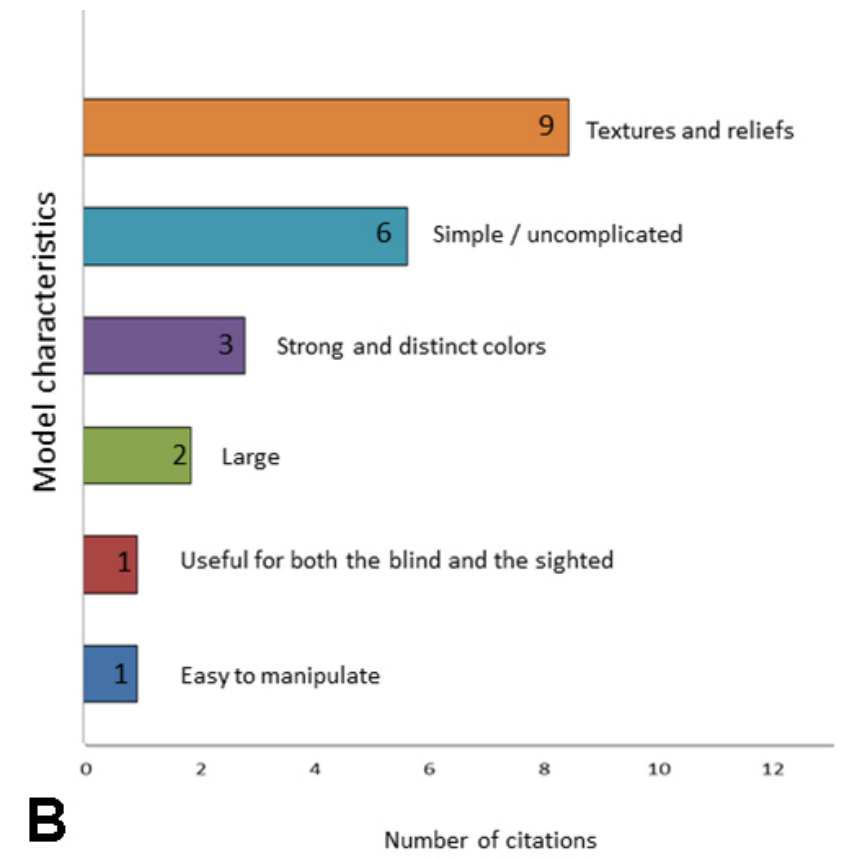

Fig. 2. (A) Frequency of citations of different adaptations used in morphological subject classes applied to EUF VI students. (B) Incidence of citations concerning ideal model characteristics identified in EUF VI student responses. 
Table II. Structures and standardized materials used in the microscopy board models developed herein.

\begin{tabular}{lc}
\hline Tissue structure & $\begin{array}{c}\text { Representative material } \\
\text { (standardized) }\end{array}$ \\
\hline Epithelial tissue & Suede \\
Connective tissue & Cork \\
Cell nuclei & Beads \\
Blood vessels & EVA circle \\
\hline
\end{tabular}

When models were used as an aid to learning contribution, as in question 4, acceptance was unanimous among the investigated students, who considered this resource as a strong ally in the process of teaching and learning morphological disciplines.

The ideal characteristics for the efficiency of a model as a didactic instrument were pointed out (Table II, question 5), as follows: (i) representative textures and reliefs, (ii) large sizes, (iii) simple representations (with few details), (iv) Braille subtitles and (v) bold colors to help students with low vision (Fig. 2B).

This result indicates that certain characteristics should be taken into account when constructing models that aim to help VI student to appropriate images and morphological contents. Models that contain too much information and detail are not appropriate for teaching the VI. However, once models that meet the criteria indicated by the students in this investigation are developed, they can be used by VI students as well as sighted students, which favors inclusion.

Building models for morphology teaching: Based on the information provided by the students about how models used for the perception of histological structures should be represented, microscopy board models were constructed from images taken from atlases. Several prototypes (Fig. 3) were constructed, until a set of nine boards (Fig. 4) were created, made primarily of wood (10mm thick plywood), all measuring the size of an A4 sheet of paper $(21 \mathrm{~cm}$ high $\mathrm{x}$ $30 \mathrm{~cm}$ wide). The choice of these dimensions and materials is related to easy transport, handling and storage. To ensure model longevity, no perishable materials, such as grains or seeds, were used. However, an important material selection criterion was adopted, namely, low costs. Khitab et al. (2013) state that we are in the age of science and technology, in which scientific inventions and their wonders are highly valued and thus it is mistakenly believed that high investments in equipment, gadgets and modern and sophisticated devices are required in order to maintain proper student motivation. However, the authors claim, and we corroborate this statement, that it is possible to equip laboratories and classrooms with low-cost materials to democratize access to information (Khitab et al.).

An important concern was also noted concerning material standardization that represented each structure of each image reproduced in the developed models, as displayed in Table II. Thus, each cellular structure was represented in the same way on different boards whenever it was repeated, facilitating identification.

Evaluation of the relief models from biological tissue optical microscopy images: Two assessment moments were carried out: One conducted by EUF VI students in Spain, and another by UVV sighted students in Brazil. The perspective of serving both groups comes from the idea that true inclusion occurs when the teacher can use shared and accessible strategies for all students (disabled or not) in the same class (McLeskey \& Waldron).

Therefore, the models were first assessed through ae class comprising first-year EUF VI students. It is worth noting that no student (neither in Brazil, nor in Spain) had
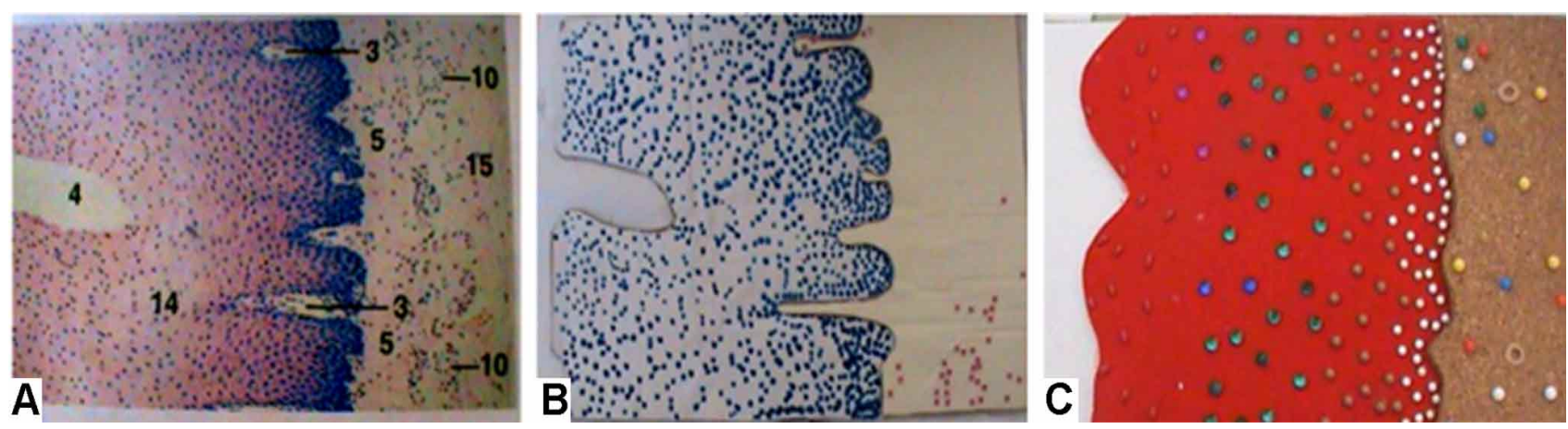

Fig. 3. Evolution of microscopy board model prototypes. (A) Image of a stratified squamous epithelial tissue reproduced from a histology atlas; (B) Prototype made of cardboard using blue plastic glue to reproduce the epithelial cell nuclei, a cardboard step to reproduce the basal membrane and pink beads to represent the fibroblast nuclei in connective tissue; (C) Final version of the model made of wood, with suede representing the epithelial tissue, several beads of different shapes and colors indicating cell nuclei, and cork asthe texture chosen to represent the connective tissue. 
COMARÚ, M. W. ; LOPES, R. M.; GALVÃO, C. \& COUTINHO, C. M. L. M. Histology for the visually impaired: a study applying models at universities in Spain and Brazil. Int. J. Morphol., 39(I):235-243, 2021.

previously studied the content presented and evaluated in the test class. After content presentation, the students were

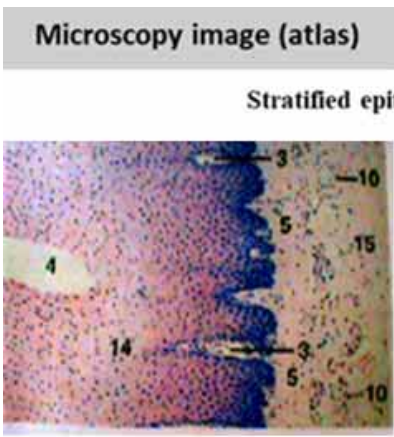

\section{Model}

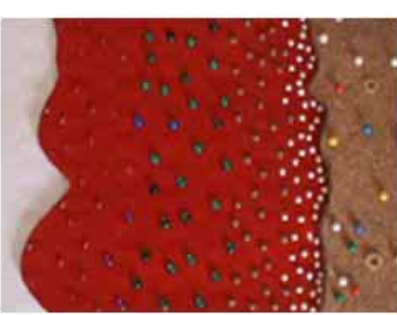

Adipose tissue (400x)
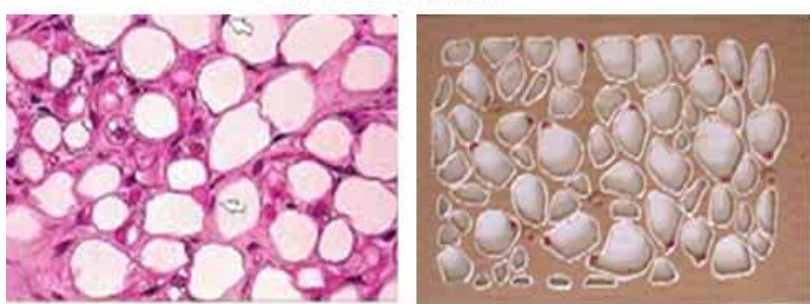

Cancellous bone tissue (400x)

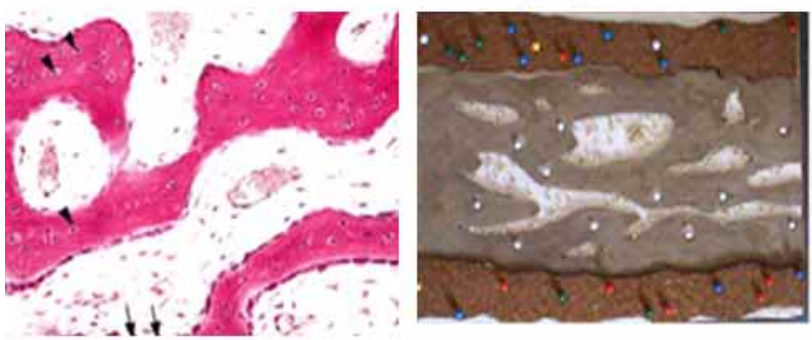

Cartilaginous tissue (400X)
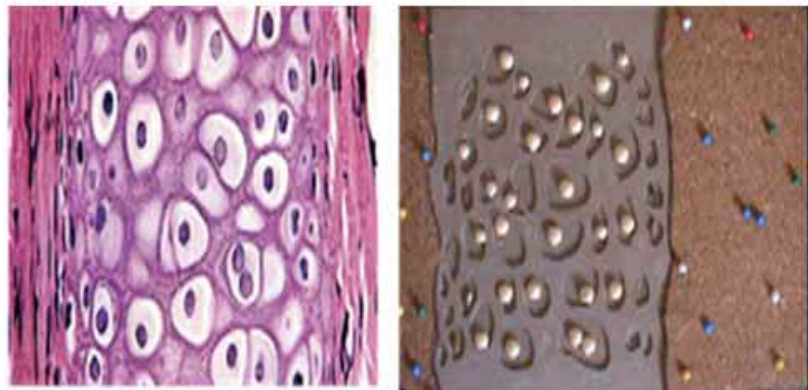

Compact bone tissue (400x)
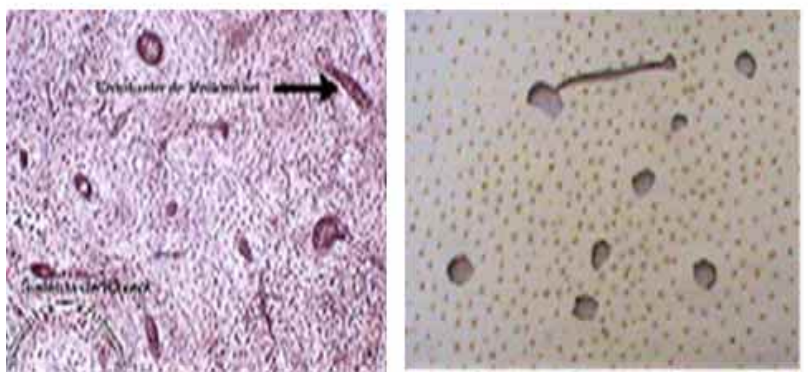

separated into a group with access to the models and another without, followed by an individual content test.

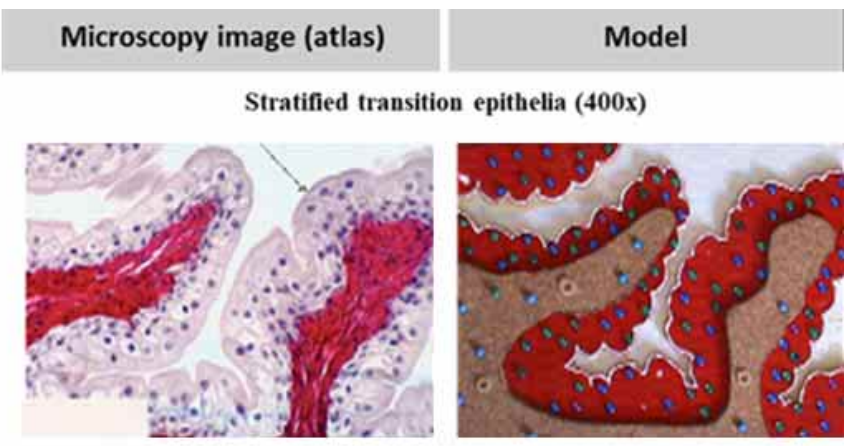

Skeletal striated muscle tissue $(100 x)$

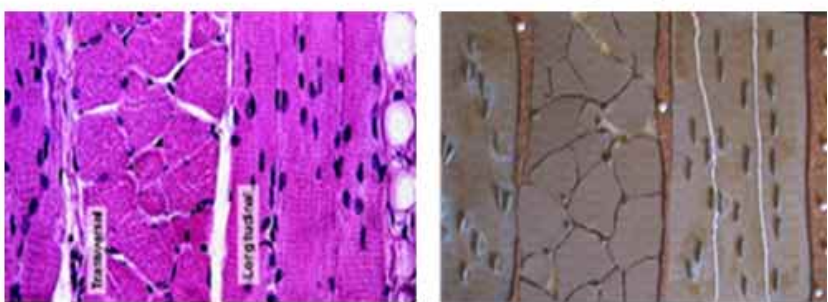

Ciliated pseudostratified epithelial tissue (400x)
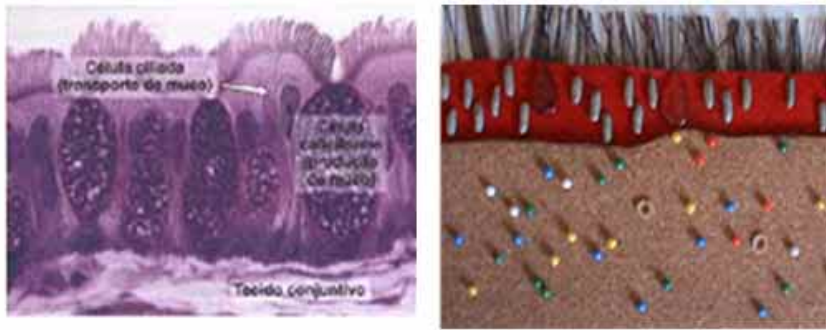

Simple cylindrical epithelial tissue with microvilli (100x)
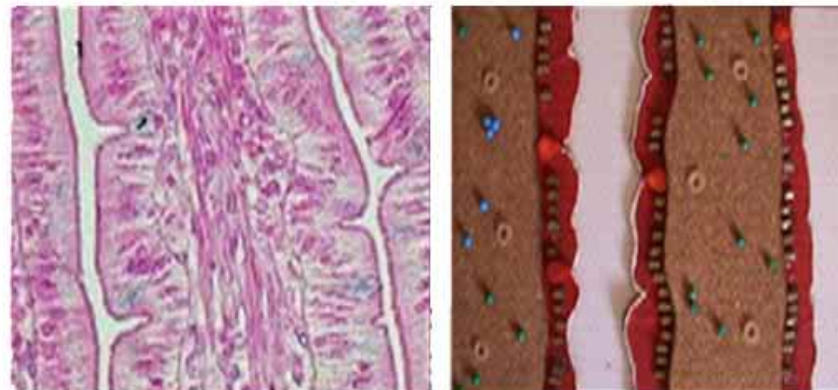

Fig. 4. Optical microscopy images of histological sections (left) and their respective relief models (right). 
The results indicate a significant intra-group difference in content assimilation efficiency, where the group with access to the models displayed a better performance (Fig. 5A).

Sighted students participating in the research (students who were studying morphology in the Biological Sciences course in Brazil) were divided into three groups, one of which took a traditional hands-on class using the microscope, while the other used the models and the third used both types of teaching materials. All performed tests on the content presented in the previous week. Other studies point (Goldberg \& Dintzis, 2007; Schencke \& Hidalgo, 2011; Lee et al., 2020) that the change in microscopy teaching and learning strategies, such as virtual microscopy and collaborative activities are not associated with any negative impact on student performance in practical exams.

A significant difference in content assimilation efficiency was observed between the model and non-model groups and for both groups in relation to the access to both forms of the didactic material. The group presenting the best content assimilation efficiency was the one that used both the models and the microscope. When comparing the group that used the microscope only to the group that used the models only, the best content assimilation efficiency was observed in the group that used models (Fig. 5B).

Final comments: We recognize that it may seem to the reader that this paper promotes a comparison between the two groups of students investigated in different circumstances. But it's not the case. We brought the results of two groups that we recognize to be different precisely to show that inclusion is defined as a proposal for education in diversity. At ONCE's EUF in Madrid, VI students have access to morphological subject content through instruments and teaching materials developed by the school itself and which have aided significantly in content assimilation, being considered strong allies in the learning process, although they still do not fully meet the perceptive needs of VI students.

The methods applied to blind and sighted students are different and, therefore, do not allow a comparison between them (and certainly the way each group uses the model is also quite different). Nor was that the purpose, after all, the idea of a resource that serves everyone equally, is idealistic. The perspective in this case, was to show how the models can be used both in a class with blind people, as well as in a visionary, and thus, we have support for such statement. From the perspective of using these models, it is to observe how it would be to use them in a mixed class.

The results reported herein indicate that the use of relief models can represent an important pedagogical strategy used to teach morphological subjects to the VI, according to student opinions. In the same way, students indicate that the construction of these models must comply with certain criteria for enhanced efficiency, such as the fact that they must contain texture and relief elements, must not contain excessive amount of information, and must present strong and distinct colors to aid in VI student content assimilation. The importance of developing materials such as relief boards was also highlighted from an inclusion perspective, as these materials can be used in both blind and VI classes, together. Thus, the present study contributes to morphological subject teachers who eventually receive VI students in their classes, to understand where to start on the path to an inclusive and pedagogically coherent learning process.
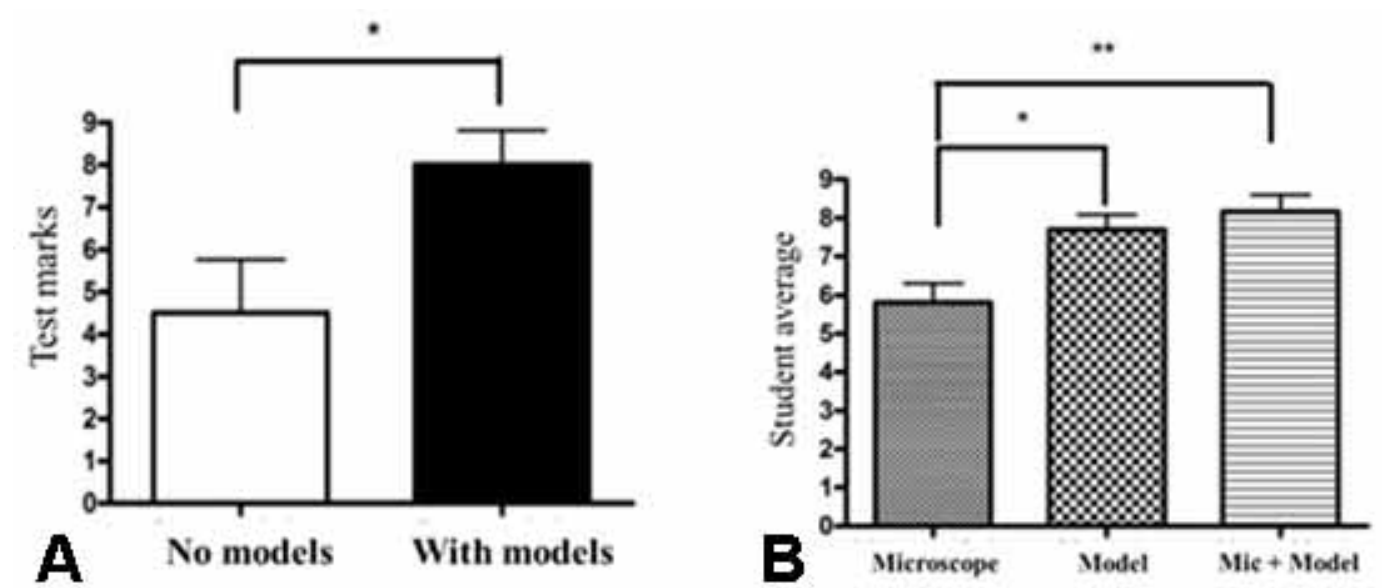

Fig. 5. (A) Comparison between the marks obtained by visually impaired students during the histology model evaluation test class. (B) Comparison of mark averages obtained by sighted students during the evaluation test of the handmade microscopy board histology models. 


\section{CONCLUSION}

By developing tactile models of histological slide images, taking as a parameter the characteristics pointed out by the students themselves, and evaluating them in practical morphology classes, it was possible to realize that their use promotes potentially inclusive and efficiently productive morphology classes, both for students blind as well as those who see.

\section{ACKNOWLEDGMENTS}

The authors would like to thank CAPES and INOVAFiocruz for the support received. The authors thank the entire team of the Oficina de acción solidaria y cooperación - Universidad Autónoma de Madrid, in the form of its directors: $\mathrm{Ph}$ D. Silvia Arias Careaga and PhD. Pedro Martínez Lillo. The authors also thank the team at the Escuela Universitaria de Fisioterapia de la ONCE, especially its director PhD. Javier Sainz de Murieta y Rodeyro.

COMARÚ, M. W. ; LOPES, R. M.; GALVÃO, C. \& COUTINHO, C. M. L. M. Histología para discapacitados visuales: un estudio aplicando modelos en universidades de España y Brasil. Int. J. Morphol., 39(1):235-243, 2021.

RESUMEN: Este estudio tuvo como objetivo desarrollar modelos que reproduzcan imágenes histológicas de diapositivas y las evalúen con estudiantes ciegos y videntes desde una perspectiva de inclusión. Los estudiantes no videntes respondieron un cuestionario con preguntas sobre las características ideales de un modelo. En base a las respuestas y las imágenes de microscopía óptica de los atlas histológicos, se construyeron nueve modelos con materiales estandarizados. Los modelos fueron probados en diferentes momentos con estudiantes no videntes y con estudiantes videntes. Nuestros resultados indican que en la enseñanza de la morfología, según los propios estudiantes, se debe hacer uso de recursos adicionales tal como los modelos. Las características ideales para la eficiencia del modelo como herramienta de enseñanza fueron las texturas y relieves representativos. Los modelos construidos fueron evaluados por estudiantes ciegos en España y estudiantes videntes en Brasil. Desde una perspectiva inclusiva, es ideal que un mismo material pueda satisfacer las demandas de todo tipo de estudiantes. El uso de los modelos desarrollados mejoró el aprendizaje en ambos grupos, incluso cuando se combinó con microscopios para estudiantes videntes. Según las opiniones de los estudiantes, el uso de modelos en relieve puede representar una importante estrategia pedagógica utilizada en la enseñanza de la morfología. También se destacó la importancia de desarrollar esos materiales desde una perspectiva de inclusión, ya que estos materiales pueden ser utilizados en clases mixtas, todos los estudiantes juntos, en aprendizaje cooperativo. Este estudio ayuda a los profesores de asignaturas morfológicas que enseñan a los estudiantes con discapacidad visual a conocer la vía hacia un proceso de aprendizaje inclusivo y pedagógicamente coherente.

PALABRAS CLAVE: Estudiantes universitarios con discapacidad visual; Modelos; Enseñanza de la morfología.

\section{REFERENCES}

Abed, M. G. \& Shackelford, T. K. Educational support for Saudi students with learning disabilities in higher education. Learn. Disabil. Res. Pract., 35(1):36-44, 2020.

Araújo-Jorge, T. C.; Cardona, T. S.; Mendes, C. L. S.; Henriques-Pons, A.; Meirelles, R. M. S.; Coutinho, C. M. L. M.; Aguiar, L. E. V.; Meirelles, M. N. L.; de Castro, S. L.; Barbosa, H. S.; et al. Microscopy images as interactive tools in cell modeling and cell biology education. Cell Biol. Educ., 3(2):99-110, 2004.

Avila, V. Analisis de la Problemática de los Alumnos con Deficiencias Visuales en los Estudios Universitarios: El caso de la Universidad de Valencia. Tesis de Doctorado, Valencia, Universidad de Valencia, 1998.

Barbosa-Lima, M. d. C. d. A. Camargo, E. P. de. Ensino de óptica para alunos cegos: possibilidades. Curitiba: CRV, 2011. Educ. Rev. (Curitiba), (44):311-3, 2012.

Boyd-Kimball, D. Adaptive instructional aids for teaching a blind student in a nonmajors college chemistry course. J. Chem. Educ., 89(11):13959, 2012.

Caballero González, J. E. Apuntes para la historia de la docencia de la Histología en Cuba. Siglo XX. Rev. EDUMECENTRO, 4(3):28-41, 2012.

Campos-Sánchez, A.; López-Núñez, J. A.; Carriel, V.; Martín-Piedra, M. Á.; Sola, T., \& Alaminos, M. Motivational component profiles in university students learning histology: a comparative study between genders and different health science curricula. BMC Med. Educ., 14:46, 2014.

Comarú, M. W.; Oliveira, R. S.; Santana, T. F. P. \& Coutinho, C. M. L. M.. Inclusão no Ensino Superior no Brasil: Panorama geral e mapeamento de deficientes visuais em cursos da área biomédica no estado do Espírito Santo. Rev. Eletron. Debates Educ. Cient. Tecnol., 4(1):32-51, 2014

Felszeghy, S.; Pasonen-Seppänen, S.; Koskela, A.; Nieminen, P.; Härkönen, K.; Paldanius, K. M. A.; Gabbouj, S.; Ketola, K.; Hiltunen, M.; Lundin, M.; et al. Using online game-based platforms to improve student performance and engagement in histology teaching. BMC Med. Educ., 19(1):273, 2019.

García, M.; Victory, N.; Navarro-Sempere, A. \& Segovia, Y. Students' views on difficulties in learning histology. Anat. Sci. Educ., 12(5):5419, 2019.

Gartner, L. P. \& Hiatt, J. L. Tratado de Histologia. 2nd ed. Rio de Janeiro, Guanabara Koogan, 2003.

Glat, R. \& Pletsch, M. D. O papel da Universidade no contexto da política de Educação Inclusiva: reflexões sobre a formação de recursos humanos e a produção de conhecimento. Rev. Educ. Espec., 23(8):34556, 2010.

Goldberg, H. R. \& Dintzis, R. The positive impact of team-based virtual microscopy on student learning in physiology and histology. $A d v$. Physiol. Educ., 31(3):261-5, 2007.

Gould, K. S.; Gilbert, A.; Pike, A. J. \& Menzies, I. J. Interactive touchscreen monitors facilitate collaborative learning of microscopy skills in an introductory-level plant biology lab. J. Biol. Educ., 53(1):47$53,2019$. 
Husmann, P. R.; O'Loughlin, V. D. \& Braun, M. W. Quantitative and qualitative changes in teaching histology by means of virtual microscopy in an introductory course in human anatomy. Anat. Sci. Educ., 2(5):218-26, 2009.

Jones, M. G.; Taylor, A. R. \& Broadwell, B. Concepts of scale held by students with visual impairment. J. Res. Sci. Teach., 46(5):506-19, 2009.

Junqueira, L. C. \& Carneiro, J. Histologia Básica. $9^{\text {th }}$ ed. Rio de Janeiro, Guanabara Koogan, 2004.

Khitab, U.; Ghaffar, A.; Zaman, A. \& Athar. An investigative study of the construction of low cost material by secondary science teachers. World Appl. Sci. J., 28(10):1427-36, 2013.

Lee, B. C.; Hsieh, S. T.; Chang, Y. L.; Tseng, F. Y.; Lin, Y. J.; Chen, Y. L.: Wang, S. H.; Chang, Y. F.; Ho, Y. L.; Ni, Y. H.; et al. A web-based virtual microscopy platform for improving academic performance in histology and pathology laboratory courses: a pilot study. Anat. Sci. Educ., 13(6):743-58, 2020.

Lee, L. M. J.; Goldman, H. M. \& Hortsch, M. The virtual microscopy database-sharing digital microscope images for research and education. Anat. Sci. Educ., 11(5):510-5, 2018.

McLeskey, J. \& Waldron, N. L. Educational programs for elementary students with learning disabilities: can they be both effective and inclusive? Learn. Disabil. Res. Pract., 26(1):48-57, 2011.

Melaku, S.; Schreck, J. O.; Griffin, K. \& Dabke, R. B. Interlocking toy building blocks as hands-on learning modules for blind and visually impaired chemistry students. J. Chem. Educ., 93(6):1049-55, 2016.

Poirier, J.; Cohen, I. \& Bernaudin, J. F. Histología. Barcelona, Masson, 2002.

Sansgiry, S. S. The future of pharmacy education: back to which basics? Pharmacotherapy, 24(5):688-9, 2004.

Schencke, C. \& Hidalgo, A. Comparison of two human histology software as complementary use in traditional education. Int. J. Morphol., 29(4):1388-93, 2011.

Smothers, S. M. \& Goldston, M. J. Atoms, elements, molecules, and matter: An investigation into the congenitally blind adolescents' conceptual frameworks on the nature of matter. Sci. Educ., 94(3):448477,2010

Tian, Y.; Xiao, W.; Li, C.; Liu, Y.; Qin, M.; Wu, Y.; Xiao, L. \& Li, H. Virtual microscopy system at Chinese medical university: an assisted teaching platform for promoting active learning and problem-solving skills. BMC Med. Educ., 14:74, 2014.

Tiznado-Matzner, G.; Bucarey-Arriagada, S. \& Lizama-Perez, R. Experience in the creation of an online platform to host three-dimensional models of real anatomical pieces to be shared as Open Educational Resources (OER). Int. J. Morphol., 37(4):1267-71, 2019.

Witt-Enderby, P. A. \& McFalls-Stringert, M. A. The integration of basic cell biology concepts into the practice of pharmacy. Am. J. Pharm. Educ., 68(2):1-9, 2004.

\author{
Corresponding author: \\ Michele Waltz Comarú, PhD. \\ Institute of Education \\ University of Lisbon \\ Alameda da Universidade \\ 1649-013 \\ Lisboa \\ PORTUGAL
}

Email: michele.comaru@ifrj.edu.br

Received: 26-08-2020

Accepted: 22-10-2020 